\title{
EFEKTIVITAS PELAKSANAAN SUPERVISI KEPALA SEKOLAH TERHADAP STANDAR PROSES PEMBELAJARAN PENDIDIKAN AGAMA ISLAM DI SMK NEGERI 1 KAIDIPANG KABUPATEN BOLAANG MONGONDOW UTARA
}

\author{
Ismail Lauma dan Siti Asiah T. Pido \\ email: lauma01.ismail@gmail.com
}

\begin{abstract}
ABSTRAK
Kajian ini menganalisis efektivitas pelaksanaan supervisi kepala sekolah terhadap standar proses pembelajaran PAI, dan faktor-faktor yang mempengaruhinya. Hasil penelitian bahwa supervisi terhadap standar proses pembelajaran PAI belum efektif karena keterbatasan waktu kepala sekolah sehingga menunjuk guru senior untuk membantunya. Selain itu kinerja kepala sekolah lebih menitikberatkan pada pemenuhan aspek teknis administratif daripada aspek akademis dan pembelajaran; pengawasan lebih ke segi fisik pendukung pembelajaran. Faktor penunjang efektivitas supervisi terhadap standar proses pembelajaran PAI yakni kompetensi kepala sekolah dan kemampuan guru dalam pembelajaran. Faktor penghambat terdiri atas keterbatasan waktu kepala sekolah dan faktor keterbatasan sumber daya pendidikan.
\end{abstract}

Kata Kunci: Supervisi, Standar Proses 


\section{A. Pendahuluan}

Undang-Undang RI Nomor 20 Tahun 2003 tentang Sistem Pendidikan Nasional bahwa tugas kepala sekolah sebagai supervisor yang diharapkan dapat setiap kali berkunjung ke kelas dan mengamati kegiatan guru yang mengajar. ${ }^{1}$ Mengingat di bidang pendidikan diperlukan penyelia (supervisor) yang dapat berdialog serta membantu pertumbuhan pribadi guru sesuai dengan profesinya.

Kepala sekolah mempunyai peranan dalam melaksanakan supervisi karena bertanggungjawab terkait dengan pengembangan profesi guru terfokus pada ketiga aspek kemampuan guru yakni: kemampuan merencanakan; melaksanakan, dan mengevaluasi pembelajaran agar berlangsung optimal. ${ }^{2}$

Sebagai tolok ukur keberhasilan kepala sekolah dalam pelaksanaan supervisi adalah sampai sejauhmana perubahan telah dicapai, akibat pengaruh pelaksanaan supervisi terhadap kinerja guru. Keberhasilan ini tentu didukung oleh pengetahuan dan keterampilan yang dimiliki kepala sekolah terhadap fungsi, prinsip dan penerapan teknis supervisi itu sendiri.

Sebagai supervisor kepala sekolah belum memiliki kompetensi menjawab masalah antara lain: kepala sekolah merasa supervisi adalah tugas pengawas; kegiatan supervisi menekankan aspek administrasi dan mengabaikan proses pembelajaran; supervisor enggan melaksanakan supervisi karena perbedaan hierarki jenjang pendidikan; jabatan rangkap dari kepala sekolah, yakni sebagai administrator sekaligus pimpinan sekolah sehingga supervisi sering terabaikan, karena kesibukan; minim pengetahuan supervisor terkait tugasnya. ${ }^{3}$

Kepala sekolah sebagai supervisor mempunyai tanggung jawab untuk peningkatan kemampuan guru dalam mengelola kegiatan pembelajaran di sekolah serta mempunyai peranan yang sangat penting terhadap perkembangan dan kemajuan sekolah. Jadi harus

\footnotetext{
${ }^{1}$ Depdiknas, Undang-undang Republik Indonesia Nomor 20 Tahun 2003 Tentang Sistem

Pendidikan Nasional, (Bandung: Citra Umbara; 2003), h. 23.

${ }^{2}$ Wina Sanjaya, Strategi Pembelajaran, (Jakarta: Prenada Media Group, (2008), h. 45.
} 
melaksanakan supervisi secara baik dan benar sesuai dengan prinsip-prinsip supervisi serta teknik dan pendekatan yang tepat.

Tugas seorang supervisor adalah membantu, mendorong dan memberikan keyakinan kepada guru, bahwa proses pembelajaran dapat dan harus diperbaiki pengembangan berbagai pengalaman, pengetahuan, sikap dan keterampilan guru harus dibantu secara profesional sehingga guru tersebut dapat berkembang dalam pekerjaannya yaitu untuk meningkatkan efektifitas dan efisiensi proses pembelajaran.

Persoalan-persoalan yang timbul di lapangan yang dihadapi oleh pendidik dan tenaga kependidikan, diusahakan untuk diatasi seketika dengan bimbingan maupun koreksi oleh kepala sekolah tidak semata-mata bersifat birokratis, tetapi bersifat klinis (pembinaan teknis edukatif). Mengingat lingkup tugas kepala sekolah sebagai supervisor mencakup berbagai aspek, maka diperlukan juga modal pengetahuan dan wawasan yang cukup luas. ${ }^{3}$

Supervisi yang dilakukan kepala sekolah antara lain untuk meningkatkan kompetensi guru dalam kegiatan pembelajaran, sehingga diharapkan memenuhi misi pembelajaran yang diembannya atau misi pendidikan nasional dalam lingkup lebih luas. ${ }^{4}$

Salah satu indikator mengetahui keberhasilan Pendidikan Agama Islam dapat dilihat dari aspek proses pembelajaran. Proses pembelajaran merupakan inti dari proses pendidikan secara keseluruhan dengan guru sebagai pemegang peranan utama. Karena proses pembelajaran mengandung serangkaian perbuatan pendidik/guru dan peserta didik atas dasar hubungan timbal balik yang berlangsung dalam situasi edukatif untuk mencapai tujuan tertentu.

Dalam salinan lampiran Keputusan Menteri Pendidikan dan Kebudayaan Nomor 65 Tahun 2013 tentang Standar Proses secara lebih jelas menerangkan tentang pelaksanaan proses pembelajaran sebagai berikut: Setiap satuan pendidikan melakukan perencanaan pembelajaran, pelaksanaan proses pembelajaran serta penilaian proses pembelajaran untuk meningkatkan efisiensi dan efektivitas ketercapaian kompetensi lulusan.

\footnotetext{
${ }^{3}$ Made Pidarta, Pemikiran Tentang Supervisi Pendidikan (Jakarta: Bumi Aksara, 2002), h. 26. ${ }^{4}$ Nick Cowel,dkk, Teknik Mengembangkan Guru dan Peserta didik Buku

Panduan Untuk Penilik Sekolah Dasar, (Jakarta, t.p., 2005), h. vii
} 
Berdasarkan observasi awal yang penulis lakukan menunjukkan bahwa praktik pengawasan di lingkungan SMK Negeri 1 Kaidipang yakni pengawasan kepala sekolah masih mengutamakan aspek teknis administratif daripada aspek akademis dan pembelajaran; pengawasan lebih ke segi fisik pendukung pembelajaran, seperti pengelolaan dana, pegawai, bangunan, alat dan fasilitas lainnya. Kendati pun telah dilakukan pengawasan terhadap kemampuan guru mengajar secara profesional dan sesuai dengan kaidah-kaidah pedagogik namun pengawasan kurang menekankan pada implementasi standar proses pembelajaran dalam penilaian kinerja oleh kepala sekolah. Padahal kenyataan yang ditemui bahwa guru PAI masih belum menerapkan standar proses pembelajaran yang ditetapkan karena kegiatan awal, inti dan penutup masih didominasi oleh guru dari pada peserta didik seperti tidak diterapkannya kegiatan mengamati, menanyai, mengkomunikasikan pada peserta didik dan belum menekankan pada pembelajaran yang kontekstual.

\section{B. Landasan Teori}

\section{Konsep Supervisi dan Standar Proses PAI}

\section{Pengertian Supervisi}

Supervisi secara etimologi berasal dari kata "super" dan "visi”yang mengandung arti melihat dan meninjau dari atas atau menilik dan menilai dari atas yang dilakukan oleh pihak atasan terhadap aktivitas, kreativitas, dan kinerja bawahan. ${ }^{5}$ Terdapat beberapa istilah yang hampir sama dengan supervisi bahkan dalam pelaksanaannya istilah-istilah tersebut sering digunakan. secara bergantian. Istilah-istilah tersebut, antara lain, pengawasan, pemeriksaan, dan inspeksi. Pengawasan mengandung arti suatu kegiatan untuk melakukan pengamatan agar pekerjaan dilakukan sesuai dengan ketentuan. Pemeriksaan dimaksudkan untuk melihat bagaimana kegiatan yang dilaksanakan telah mencapai tujuan. Inspeksi dimaksudkan untuk mengetahui kekurangan-kekurangan atau kesalahan yang perlu diperbaiki dalam suatu pekerjaan. ${ }^{6}$ Kemudian berkembang supervisi yang bersifat ilmiah, ialah: (1) Sistematis, artinya dilaksanakan secara teratur, berencana dan kontinu. (2) Obyektif dalam pengertian ada data yang didapat berdasarkan observasi nyata bukan berdasarkan tafsiran pribadi. (3) Menggunakan alat pencatat yang dapat memberikan informasi sebagai umpan balik untuk

\footnotetext{
${ }^{5}$ E. Mulyasa, Manajemen Berbasis Sekolah, (Bandung: Remaja Rosdakarya, 2000), h.154

${ }^{6}$ Piet A.Sahertian, Konsep Dasar dan Teknik Supervisi Pendidikan Dalam Rangka Pengembangan SDM, (Jakarta, 2000), h.
} 
mengadakan penilaian terhadap proses pembelajaran di kelas. Supervisi adalah suatu aktivitas pembinaan yang direncanakan untuk membantu para guru dan pegawai sekolah dalam melakukan pekerjaan secara aktif. Supervisi yaitu bantuan dalam mengembangkan situasi pembelajaran ke arah yang lebih baik, dengan jalan memberikan bimbingan dan pengarahan pada guru dan petugas lainnya untuk meningkatkan kualitas kerja mereka di bidang pembelajaran dengan segala aspeknya. ${ }^{5}$ Supervisi yaitu pelayanan yang disediakan oleh pemimpinan untuk membantu agar menjadi semakin cakap atau terampil dalam melaksanakan tugas-tugasnya, sesuai dengan tuntutan perkembangan dan kemajuan ilmu pengetahuan dibidang tugas tersebut. Supervisi mengandung beberapa kegiatan pokok, yaitu pembinaan kontinu, pengembangan kemampuan profesional personil, perbaikan situasi pembelajaran, dengan sasaran akhir pencapaian tujuan pendidikan dan pertumbuhan pribadi peserta didik.

\section{Teknik Supervisi}

Purwanto menyatakan teknik yang digunakan oleh supervisi dalam hal ini adalah kepala sekolah dibagi dua yaitu teknik perseorangan dan teknik kelompok.

a. Teknik Perseorangan (individual)

1. Mengadakan kunjungan kelas (class room visitation). Kunjungan kelas yaitu kunjungan sewaktu-waktu yang dilakukan oleh seorang supervisor. Kegiatan ini untuk melihat apa kekurangan atau kelemahan yang sekiranya masih perlu diperbaiki dalam proses pembelajaran.

2. Mengadakan kunjungan observasi (observation visits). Kepala sekolah menugaskan guru untuk melihat atau mengamati seorang guru yang sedang mendemonstrasikan cara-cara mengajar suatu mata pelajaran tertentu.

3. Membimbing guru-guru tentang cara-cara mempelajari pribadi peserta didik dan atau mengatasi problema yang dijalani peserta didik.

4. Membimbing guru-guru dalam hal-hal yang berhubungan dengan pelakanaan kurikulum sekolah, antara lain: menyusun program semester, menyusun RPP, mengorganisasikan kegiatan pengelolaan kelas, melaksanakan teknik evaluasi pembelajaran, menggunakan media dan sumber, mengorganisasikan kegiatan peserta didik dalam bidang ekstrakurikuler, studi tour.

b. Teknik Kelompok 
1) Mengadakan pertemuan atau rapat (meeting)

2) Mengadakan diskusi kelompok (group discussions)

3) Mengadakan penataran (In-Service Training) ${ }^{10}$

Teknik supervisi kelompok dilakukan melalui penataran sudah banyak dilakukan. Misalnya penataran untuk guru-guru bidang studi tertentu. Penataran tentang metodologi pembelajaran dan penataran tentang administrasi pendidikan. c. Konsep Standar Proses Pembelajaran PAI

Sesuai dengan amanat Peraturan Pemerintah Nomor 32 tahun 2013 tentang Standar Nasional Pendidikan salah satu standar yang harus dikembangkan adalah standar proses. Standar proses adalah standar nasional pendidikan yang berkaitan dengan pelaksanaan pembelajaran pada satuan pendidikan untuk mencapai kompetensi lulusan. Standar proses berisi kriteria minimal proses pembelajaran pada satuan pendidikan dasar dan menengah di seluruh wilayah hukum Negara Kesatuan Republik Indonesia. Standar proses ini berlaku untuk jenjang pendidikan dasar dan menengah pada jalur formal, baik pada sistem paket maupun pada sistem kredit semester.

Standar proses adalah standar nasional pendidikan yang berkaitan dengan pelaksanaan pembelajaran pada satu satuan pendidikan untuk mencapai standar kompetensi lulusan. Standar proses, baik yang berkaitan dengan perencanaan, pelaksanaan, penilaian, dan pengawasan pembelajaran dikembangkan oleh BSNP, dan ditetapkan dengan Peraturan Menteri.

Dari uraian di atas disimpulkan bahwa standar proses pembelajaran PAI meliputi perencanaan, pelaksanaan, penilaian dan pengawasan proses pembelajaran untuk terlaksananya proses pembelajaran PAI yang efektif dan efisien.

\section{Pembahasan}

Efektivitas Pelaksanaan Supervisi Kepala Sekolah terhadap Standar Proses Pembelajaran PAI di SMK Negeri 1 Kaidipang Efektivitas dalam suatu kegiatan berkenaan dengan sejauhmana supervisi yang direncanakan oleh kepala sekolah atau dapat diinginkannya dapat terlaksana atau tercapai. Supervisi sebagai kegiatan pemberian bantuan dan bimbingan kepada guru untuk mencapai profesionalisme. 
Pengawasan kepala sekolah masih mengutamakan aspek teknis administratif daripada aspek akademis dan pembelajaran; pengawasan lebih ke segi fisik pendukung pembelajaran, seperti pengelolaan dana, pegawai, bangunan, alat dan fasilitas lainnya. Kendati pun telah dilakukan pengawasan terhadap kemampuan guru mengajar secara profesional dan sesuai dengan kaidah pedagogik namun pengawasan kurang menekankan pada implementasi standar proses pembelajaran dalam penilaian kinerja oleh kepala sekolah.

Sebagai kepala sekolah berupaya mewujudkan impiannya menjadikan SMK Negeri 1 Kaidipang sebagai sekolah yang menerapkan standar nasional pendidikan. Program prioritas kepala sekolah pada standar ini adalah memperbaiki kualitas SDM, dengan target minimal semua guru harus berijazah sarjana sesuai bidangnya. Sekolah ini memiliki 3 orang guru PAI, yang terdiri dari 3 orang guru PAI yang berstatus PNS dan dari seluruh guru tinggal 1 orang guru PAI berstatus guru belum tersertifikasi kendati sudah berstatus PNS. Dilihat dari tingkat pendidikannya, dari 3 orang guru PAI seluruhnya sudah bergelar sarjana pada bidang pendidikan agama Islam.

Data guru dan jadwal supervisi dalam proses pembelajaran PAI di SMK Negeri 1 Kaidipang, dapat dilihat pada tabel di bawah ini:

Tabel 1

Jadwal Supervisi Bagi Guru PAI di SMK Negeri 1 Kaidipang

\begin{tabular}{|c|c|c|c|c|}
\hline No & Nama & $\begin{array}{l}\text { Hari/Tanggal } \\
\text { Supervisi }\end{array}$ & $\begin{array}{l}\text { Mata } \\
\text { Pelajaran }\end{array}$ & Kelas \\
\hline 1 & Lisfon Lahiya & $\begin{array}{l}\text { Sesuai Jadwal } \\
\text { Belajar }\end{array}$ & PAI & XI \\
\hline 2 & Mansyur Suleman & $\begin{array}{l}\text { Sesuai Jadwal } \\
\text { Belajar }\end{array}$ & PAI & $\mathrm{X}$ \\
\hline 3 & $\begin{array}{l}\text { Sofyan Andry } \\
\text { Monoarfa }\end{array}$ & $\begin{array}{l}\text { Sesuai Jadwal } \\
\text { Belajar }\end{array}$ & PAI & XII \\
\hline
\end{tabular}




\section{Sumber Data: Profil SMK Negeri 1 Kaidipang}

Berdasarkan tabel di atas tampak bahwa guru PAI berstatus PNS terdiri atas tiga orang yang dilakukan perencanaan terkait dengan supervisi oleh kepala sekolah sesuai dengan jadwal yang ditentukan berdasarkan jadwal belajar peserta didik namun pelaksanaannya kepala sekolah melakukan supervisi khususnya pada aspek standar proses pembelajaran PAI dengan menugaskan kepada wakil kepala sekolah untuk membantu karena sudah terlalu banyak guru yang harus disupervisi oleh kepala sekolah.

Berdasarkan hasil wawancara yang dilakukan diperoleh gambaran tentang penerapan supervisi oleh kepala sekolah terhadap guru di SMK Negeri 1 Kaidipang. Hasil pengamatan terhadap penerapan supervisi mulai dari perencanaan sampai kepada pelaksanaannya oleh kepala sekolah pada tabel berikut ini:

Tabel 2

Penerapan Supervisi terhadap Guru PAI

\begin{tabular}{|l|l|l|}
\hline No & Aspek Yang & \multicolumn{1}{c|}{ Hasil Pengamatan } \\
\hline 1 & $\begin{array}{l}\text { Diobservasi } \\
\text { supervisi }\end{array}$ & $\begin{array}{l}\text { Kepala sekolah menyusun perencanaan } \\
\text { program supervisi untuk satu semester dan } \\
\text { merencanakan supervisi bagi guru yang } \\
\text { mengalami masalah secara insidentil }\end{array}$ \\
\hline 2 & Melaksanakan & $\begin{array}{l}\text { Kepala sekolah melaksanakan program } \\
\text { supervisi untuk satu semester dan }\end{array}$ \\
\hline
\end{tabular}




\begin{tabular}{|l|l|l|} 
& supervisi & $\begin{array}{l}\text { melaksanakan supervisi bagi guru yang } \\
\text { mengalami masalah dalam pembelajaran PAI }\end{array}$ \\
\hline 3 & $\begin{array}{l}\text { Kepala sekolah mengevaluasi hasil } \\
\text { perencanaan dan pelaksanaan program }\end{array}$ \\
evaluasi/umpa & $\begin{array}{l}\text { mengevaluasi hasil perencanaan dan } \\
\text { n balik }\end{array}$ & $\begin{array}{l}\text { pelaksanaan supervisi bagi guru yang } \\
\text { mengalami masalah dalam pembelajaran PAI }\end{array}$ \\
\hline
\end{tabular}

Sumber Data: Lembar Observasi Penelitian

Data di atas menunjukkan bahwa dalam kegiatan perencanaan kepala sekolah telah menyusun perencanaan program supervisi untuk satu semester dan merencanakan supervisi bagi guru yang mengalami masalah secara insidentil berupa pembinaan. Kepala sekolah juga melaksanakan program supervisi untuk satu semester dan melaksanakan supervisi bagi guru yang mengalami masalah dalam pembelajaran PAI. Bahkan kepala sekolah mengevaluasi hasil perencanaan dan pelaksanaan program supervisi untuk satu semester dan mengevaluasi hasil perencanaan dan pelaksanaan supervisi bagi guru yang mengalami masalah dalam pembelajaran PAI. Hasil penelitian terkait dengan temuan terkait efektivitas penerapan supervisi terhadap standar proses pembelajaran PAI:

a. Efektivitas perencanaan supervisi

Dalam kegiatan ini kepala sekolah tampaknya telah menyusun perencanaan program supervisi untuk satu semester dan merencanakan supervisi bagi guru yang mengalami masalah secara insidentil berupa pembinaan. Selain itu, kepala sekolah bersama-sama dengan guru merencanakan kegiatan supervisi di kelas dengan titik aksentuasi pada kesulitan yang dihadapi guru tersebut dalam mengajar. Sehingga tahapan ini harus berlangsung dalam suasana manusiawi sehingga guru menjadi terbuka dengan kesulitan-kesulitan yang dihadapinya dalam pembelajaran PAI di kelas.

Menurut Udin Pamili dalam wawancara bahwa kepala sekolah pada umumnya menyusun perencanaan program supervisi untuk satu semester, dengan memperhatikan pelayanan 
sekolah yang seimbang dan tujuan pembinaan yang mengacu pada visi dan misi kepala sekolah, tujuan dan prosedur. Di dalam perencanaan supervisi tersebut memuat tentang jadwal supervisi, dan bergilir kembali pada setiap semester atau setiap tahun sesuai kondisi

Pendapat tersebut jelas menunjukan bahwa kepala sekolah telah memiliki perencanaan tentang supervisi yang diarahkan pada guru yang bermasalah terutama dalam kaitan dengan standar proses pembelajaran PAI. Perencanaan yang dibuat untuk jangka waktu enam bulan atau satu semester pada masing-masing guru, dengan memperhatikan kondisi guru dalam penyusunan rencana kerjanya.

Jadi perencanaan supervisi hanya dilaksanakan sewaktu-waktu, disesuaikan dengan permintaan guru untuk disupervisi. Namun demikian kepala sekolah mengakui jumlah guru yang meminta untuk disupervisi dengan supervisi jumlahnya terbatas, karena pada umumnya guru merasa takut untuk disupervisi.

\section{b. Efektivitas pelakanaan supervise}

Supervisi adalah bentuk pengawasan yang difokuskan pada peningkatan mengajar termasuk standar proses pembelajaran PAI dengan melalui siklus yang sistematik, dalam perencanaan, pengamatan, serta analisis yang intensif dan cermat tentang penampilan mengajar yang nyata. Tekanan dalam pendekatan bersifat khusus melalui tatap muka dengan guru, yang terpusat pada perbaikan penampilan dan perilaku mengajanya.

Pada tahapan pelaksanaan ini, yaitu berupa observasi kelas, kepala sekolah mengadakan pengamatan berdasarkan kontrak yang telah disepakati. Dalam kegiatan observasi mengajar ini kepala sekolah mengamati penampilan guru dalam proses pembelajaran baik menyangkut aspek profesionalisme maupun standar proses pembelajaran PAI.

Untuk lebih jelasnya peneliti tampilkan hasil pengamatan terhadap langkah-langkah supervisi pembelajaran PAI di Kelas XI pada tabel berikut ini:

Tabel 3

Langkah-langkah Supervisi dalam Pembelajaran PAI

di Kelas XI SMK Negeri 1 Kaidipang

\begin{tabular}{|l|c|c|}
\hline No. & Aspek Yang & \\
& Diobservasi & Hasil Pengamatan \\
\hline
\end{tabular}




\begin{tabular}{|c|c|c|}
\hline 1. & Meminta RPP & $\begin{array}{l}\text { Guru PAI memberikan RPP tentang materi } \\
\text { budi pekerti kepada kepala sekolah pada } \\
\text { saat seminggu sebelum supervisi dilakukan }\end{array}$ \\
\hline 2. & $\begin{array}{l}\text { Meminta guru } \\
\text { mengajar }\end{array}$ & $\begin{array}{l}\text { Seminggu kemudian guru PAI mengajarkan } \\
\text { materi budi pekerti sesuai dengan langkah- } \\
\text { langkah yang direncanakan di kelas XI }\end{array}$ \\
\hline 3. & $\begin{array}{l}\text { Memantau } \\
\text { pembelajaran }\end{array}$ & $\begin{array}{l}\text { Kepala sekolah mencatat kejadian yang } \\
\text { dilakukan guru dan memberikan penilaian } \\
\text { baik pada RPP maupun pelaksanaannya }\end{array}$ \\
\hline 4. & $\begin{array}{l}\text { Mengadakan } \\
\text { perbaikan }\end{array}$ & $\begin{array}{l}\text { Kepala sekolah memberikan catatan kepada } \\
\text { guru PAI dan mendiskusikan kelemahan } \\
\text { serta masalah guru untuk dilakukan } \\
\text { perbaikan pada minggu berikutnya }\end{array}$ \\
\hline 5. & $\begin{array}{l}\text { Observasi kelas } \\
\text { terkait dengan } \\
\text { perbaikan }\end{array}$ & $\begin{array}{l}\text { Kepala sekolah mengamati kegiatan guru } \\
\text { PAI terkait dengan masalah dan kesulitan } \\
\text { guru serta langkah-langkah yang diambil } \\
\text { saat itu untuk mengatasinya }\end{array}$ \\
\hline
\end{tabular}

Sumber Data: Lembar Observasi Penelitian

Data di atas menggambarkan bahwa seminggu sebelum supervisi terhadap guru, kepala sekolah tampak menerima RPP dari guru untuk materi budi pekerti sesuai dengan langkahlangkah yang direncanakan di kelas XI. Selanjutnya kepala sekolah mencatat kejadian yang dilakukan guru dan memberikan penilaian baik pada RPP maupun pelaksanaannya. Kepala sekolah memberikan catatan kepada guru PAI dan mendiskusikan kelemahan serta masalah guru untuk dilakukan perbaikan pada minggu berikutnya. Terakhir, kepala sekolah mengamati kegiatan guru PAI terkait dengan masalah dan kesulitan guru serta langkahlangkah untuk mengatasinya.

Kegiatan terkait pengawasan standar proses pembelajaran PAI ditunjukkan guru ketika menyusun RPP dan perangkat pembelajaran maupun ketika mengajar dengan menunjukkan perilaku tekun, disiplin, terbuka, ulet, rajin, semangat yang tinggi, sabar, dan bertanggungjawab. Pengawas melakukan supervisor untuk menilai guru terkait standar proses pembelajaran PAI yang ditunjukkan dengan mempehatikan langkah-langkah supervisi. 
Pelaksanaan supervisi dijelaskan oleh kepala sekolah bahwa strategi pelaksanaan supervisi di kelas yaitu meminta RPP untuk dijadikan panduan dalam supervisi, selanjutnya meminta guru untuk langsung mengajar di kelas, dengan memantau pembelajarannya dari awal hingga akhir. Pelaksanaannya didasarkan pada inisiatif guru setelah terlebih dahulu mengadakan kontrak tentang bentuk perbaikan yang dikehendakinya. Setelah itu diadakan observasi kelas untuk melihat aktivitas guru di kelas terkait dengan perbaikan terhadap kemampuan mengajar.

Dari uraian tersebut secara garis besar dalam pelaksanaan supervisi tampak bahwa telah dilaksanakan oleh kepala sekolah sesuai dengan prosedur dalam hal: (1) menyusun strategi dalam pelaksanaannya, (2) mengamati seluruh tampilan yang ditunjukkan guru dalam pembelajaran yang terfokus pada rencana yang telah disepakati, (3) mengamati penampilan guru sejak awal, proses sampai dengan akhir kegiatan pembelajaran, (4) mencatat berbagai aspek yang ditemukannya dalam kegiatan pembelajaran; dan (5) kepala sekolah lebih banyak bertanya dan mendengarkan daripada memerintah atau mengarahkan.

c. Efektivitas evaluasi atau pertemuan balikan

Terkait dengan kegiatan evaluasi atau pertemuan balikan dalam pelaksanaan supervisi, kepala sekolah mengemukakan bahwa dalam kegiatan evaluasi hasil observasi pelaksaan supervisi tersebut, telah merujuk pada petunjuk pelaksanaan supervisi yang telah distandarkan oleh Kementerian Agama. Dalam kegiatan evaluasi tersebut secara umum telah mengetahui berbagai kekurangan yang dilakukan dalam prosesnya untuk selanjutnya memperbaikinya.

Identik dengan pendapat tersebut, pengawas PAI di lingkungan Kementerian Agama Kabupaten Bolaang Mongodow Utara mengemukakan pendapatnya bahwa dalam kegiatan evaluasi supervisi tersebut juga selalu berusaha untuk menemukan berbagai inovasi baru yang dapat dikembangkan dalam membina guru terkait standar proses pembelajaran PAI.

Pandangan tersebut jelas menunjukan bahwa kepala sekolah telah menunjukkan kompetensinya dengan berusaha maksimal dalam mengadakan evaluasi sambil mencari berbagai inovasi baru yang dapat dilakukan dalam pelaksanaan kegiatan supervisi. Langkah yang 
Jurnal Ilmiah AI-Jauhari (JIAJ)

Studi Islam dan Interdisipliner

Volume 3 No 2 September 2018

ISSN 2541-3430 E-ISSN 2541-3449 


\section{Penutup}

Pelaksanaan supervisi kepala sekolah terhadap standar proses pembelajaran PAI di SMK Negeri 1 Kaidipang belum sepenuhnya efektif karena masih terdapat keterbatasan waktu akibat kesibukan kepala sekolah sehingga masih menunjuk guru senior untuk membantu pelaksanaan tugasnya dalam melaksanakan supervisi terhadap guru khususnya guru PAI yang dipandang masih memerlukan bantuan dan arahan terkait pengetahuan dan kemampuannya dalam merencanakan, melaksanakan dan menindaklanjuti pelaksanaan standar proses pembelajaran PAI karena masih menimbulkan masalah yang belum semuanya terselesaikan dalam pelaksanaan supervisi kelas. Belum efektifnya pelaksanaan supervisi terhadap standar proses pembelajaran PAI dibuktikan juga oleh kinerja kepala sekolah yang lebih menitikberatkan pada pemenuhan aspek teknis administratif daripada aspek akademis dan pembelajaran; pengawasan lebih ke segi fisik pendukung pembelajaran. Faktor penunjang efektivitas pelaksanaan supervisi kepala sekolah terhadap standar proses pembelajaran PAI di SMK Negeri 1 Kaidipang yakni kompetensi kepala sekolah dan kemampuan guru dalam pembelajaran. Sedangkan faktor penghambat terdiri atas keterbatasan waktu kepala sekolah dalam melaksanakan tugas sebagai supervisor karena kesibukan yang banyak dan faktor keterbatasan sumber daya pendidikan dalam pelaksanaan supervisi terhadap standar proses pembelajaran.

Mencermati kondisi di atas maka kepala sekolah hendaknya melakukan upaya peningkatan peran strategis guru dan staff dalam meningkatkan kualitas layanan melalui serangkaian aktivitas pembinaan dan pengembangan. Salah satu bentuk peningkatan kompetensi kepala sekolah adalah melalui supervisi pembelajaran, yang diarahkan pada upaya-upaya yang sifatnya memberikan kesempatan kepada guru-guru untuk dapat berkembang secara profesional dan memiliki standar proses pembelajaran PAI yang sesuai harapan. Pengawas PAI hendaknya melakukan upaya peningkatan kompetensi supervisor dengan beberapa alasan yang mendasari pentingnya supervisi pembelajaran adalah ditunjukkan melalui upayanya meningkatkan kualitas pembelajaran di kelas. 


\section{DAFTAR PUSTAKA}

Ahmadi, Abu, Psikologi Umum, Jakarta: Rineka Cipta, 2003.

Akib, Haedar, Reaktualisasi Fungsi dan Peran Kepala Sekolah Sebagai Supervisor, Jurnal Tenaga Kependidikan Vol. 3, No. 2, Universitas Negeri Makassar: Agustus 2008.

Arikunto, Suharsimi, Prosedur Penelitian Suatu Pendekatan Praktik, Jakarta: Rineka Cipta, 2002.

As'ad, Mohammad, Seri Ilmu Sumber Daya Manusia; Psikologi Industri, Ed. IV, Yogyakarta: Liberti, 1991.

Bafadal, Ibrahim, Supervisi Pembelajaran (Teori dan Aplikasinya dalam Membina Profesional Guru), Jakarta: Bumi Aksara, 1992.

Budimansyah, Dasim, Model Pembelajaran Berbasis Portofolio, Bandung: Genesindo, 2003.

Damayanti, Sri, Profesionalisme Kepemimpinan Kepala Sekolah, Jakarta: Kuningan, 2008.

Danim, Sudarwan, Visi Baru Manajemen Sekolah, Jakarta: Bumi Aksara, Cet:1, 2006.

Departemen Agama, Al-Qur'an dan Terjemahnya, Bandung: Diponegoro, 2004.

--------, al-Qur'an dan Terjemahnya, Proyek Pengadaan Kitab Suci al-Qur'an, 2011.

Departemen Pendidikan Nasional RI, Undang-undang Republik Indonesia Nomor 20 Tahun 2003 Tentang Sistem Pendidikan Nasional, Bandung: Citra Umbara; 2003.

Djamara, Saiful Bahri, Tugas dan Fungsi Kepala Sekolah dan Implementasi Kurikulum 2004, Jakarta: Rineka Cipta, 2005.

Fathurrohman, Pupuh, dan M. Sobry Sutikno, Strategi Belajar Mengajar Melalui Penanaman; Konsep Umum dan Konsep Islam, Bandung: Refika Aditama, Cet. II, 2007.

Hendiyat S., Kepemimpinan dan Supervisi Pendidikan, Jakarta: Bina Aksara, 2004.

Imron, Ali, Pembinaan Guru di Indonesia, Jakarta: Dunia Pustaka Jaya, 1995.

Masaong, Abd. Kadim, Kepengawasan Pendidikan, Gorontalo: STIKIP Gorontalo, 2000.

Moleong, Lexy J., Metodologi Penelitian Kuantitatif, Bandung: Remaja Rosdakarya, 2001.

Muahaimin, dkk., Kawasan dan Wawasan Studi Islam, Jakarta: Kencana, 2005.

Muahaimin, Strategi Pembelajaran (Penerapannya dalam Pembelajaran Perndidikan Agama), Surabaya: Citra Media, 2003. 
Nasution, Khoiruddin, Pengantar Studi Islam, Jogjakarta: Academia, 2010.

Peraturan Pemerintah Nomor 19 Tahun 2005 Tentang Standar Nasional Pendidikan

Permendikbud Nomor 66 Tahun 2013 Tentang Standar Penilaian Pidarta, Made, Pemikiran Tentang Supervisi Pendidikan, Jakarta: Bumi Aksara, 1992.

Poerwarminta, W.J.S., Kamus Umum Bahasa Indonesia, Jakarta: Balai Pustaka, 2007.

Purwanto, Ngalim, Administrasi dan Supervisi Pendidikan, Bandung: Remaja Rosda Karya, 2005.

Rivai, Mohamad, Administrasi dan Supervisi Pendidikan, Jakarta: Jemmers, 2000.

Sahertian, Piet A., dan Ida Alaeda, Konsep Dasar dan Teknik Supervisi Pendidikan dalam Rangka Pengembangan SDM, Jakarta: t.p., 2000.

Sanjaya, Wina, Strategi Pembelajaran, Jakarta: Prenada Media Group, 2008.

Saputra, Permana Yudha, Kontribusi Budaya Kerja Sekolah terhadap Kreativitas Mengajar Guru di SMA Darul Hikam Bandung, Bandung: Skripsi UNPAD, 2007.

Senge, Peter, The Fifth Disciplines, Published by Magellan Group, 1990. Simamora, Hanry, Manajemen Sumber Daya Manusia, Yogyakarta: STIE YKPN, 2000.

Soejipto dan Raflils Kosasi, Profesi Keguruan, Jakarta: Rineka Cipta, 2000

Soetopo, Hidayat, Kepemimpinan dan Supervisi Pendidikan, Jakarta: Bina Aksara, 1982.

Subari, Supervisi Pendidikan (Dalam Rangka Perbaikan Mengajar), Jakarta: Bumi Aksara, 1994.

Soebagiyo, Atmodiwiro. Manajemen Pendidikan Indonesia. Jakarta: Azdadizya Jaya, 2000.

Tim Dosen Unversitas Negeri Malang, Manajemen Pendidikan, Malang: UNM, 2003.

Tuloli, Nani, Pengembangan Pendidikan, Sumber Daya Manusia, Budaya, Agama dan Ilmu Pengetahuan, Gorontalo: IKIP Negeri Gorontalo, 2001.

Tunggal, Amien Widjaya, Manajemen Mutu Terpadu, Jakarta: Rineka Cipta, 2003.

Undang-Undang RI Nomor 14 Tahun 2005 tentang Guru dan Dosen, Jakarta: Asa Mandiri, 2008 
Jurnal IImiah AI-Jauhari (JIAJ)

Studi Islam dan Interdisipliner

Volume 3 No 2 September 2018

ISSN 2541-3430 E-ISSN 2541-3449 